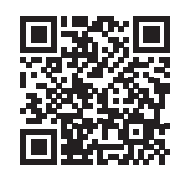

\title{
Awangardowe i ariergardowe tradycje w nowej polskiej poezji na przykładzie twórczości Andrzeja Sosnowskiego
}

Avant-garde and Arrière-garde Traditions in the Poetry of Andrzej Sosnowski

\begin{abstract}
This article attempts to answer the question of whether we can describe contemporary poetry as avant-garde? The author recognizes problems associated with defining the avant-garde as a historical phenomenon and proposes - resorting to Marjorie Perloff's concepts - a new way of interpreting contemporary poetry as an arrière-garde reconstruction of avant-garde poetics. The oeuvre of Andrzej Sosnowski is analyzed as an interesting example of how the strategy of unoriginality can be incorporated into a new model of arrière-garde poetics.
\end{abstract}


- Instytut Badań Literackich PAN

ul. Nowy Świat 72, 00-330 Warszawa

e-mail: justyna.tabaszewska@ibl.waw.pl 


\section{Uwagi wstępne}

Punktem wyjścia tego artykułu jest pewien, moim zdaniem znaczny, problem z definiowaniem tego, co obecnie można określić jako poezję, a szerzej także literaturę awangardową. W zasadzie zawsze, kiedy używa się określenia „awangarda”, ujawnia się pewna dwuznaczność terminu, odsyłającego równocześnie do pewnych historycznych prądów (szczególnie: pierwszej i drugiej awangardy) oraz szerszego zjawiska, którego ramy przekraczają wąsko definiowane okresy trwania historycznych awangard. W tym drugim znaczeniu awangarda jest prądem myślowym, który nie skończył się wraz z końcem historycznych ruchów, lecz wciąż pozostaje żywy we współczesnej literaturze.

Oczywiście, jeśli - jak sugeruje tytuł tego tekstu — zamierzam pisać o Andrzeju Sosnowskim jako o poecie awangardowym, korzystam raczej z tego drugiego, szerszego i mniej związanego z myśleniem historycznym rozumienia zjawiska. Niemniej nawet w takim przypadku problemy z definiowaniem awangardy lub awangardowości tekstu literackiego wcale nie zostają usunięte. $\mathrm{O}$ wiele łatwiej jest bowiem zdefiniować historyczny prąd niż zjawisko artystyczne, które wymyka się przypisaniu do konkretnego okresu. Z definiowaniem awangardy jako prąa myślowego, za którego cechy można uznać głównie eksperyment formalny, podważanie granic języka, odświeżanie postrzegania roli literatury i sztuki, a często również - co stanowi nawiązanie do postulatów pierwszej awangardy — dążenie do nowości, niegotowość, itp., wiążą się co najmniej dwa bardzo poważne problemy. Pierwszy z nich dotyczy ahistoryczności prądu: jeśli awangardą jako prądem myślowym nazywamy coś, co opiera się w jakimśs stopniu na postulatach historycznych awangard, ale przekracza ramy czasowe ich trwania (na przykład - uznajemy dwudziestopierwszowiecznych poetów za awangardowych), to czy oznacza to również, że możemy wskazać na twórców awangardowych przed okresem zaistnienia historycznych awangard? Jeśli zaś nie, to czy nasz opór nie wynika z przekonania, że jednak zaistnienie prądu historycznego warunkuje powstanie pewnej formacji myślowej, a więc awangarda jako prąd myślowy jest rozproszoną, mniej sformalizowaną, ale jednak kontynuacją awangardy historycznej? Z tą wątpliwością wiąże się drugi, wspominany przeze mnie problem, który można nazwać problemem świadomego włączenia i wyrazić przez pytanie: czy da się być twórcą awangardowym „niechcący”, to znaczy, nie definiując się w ten sposób lub nie korzystając — świadomie lub nieświadomie, co stanowiłoby osobny problem do rozstrzygnięcia - z tradycji awangardowych? 
Dwie powyższe wątpliwości miały pokazać, że myślenie o awangardzie jako o prądzie myślowym, choć wygodne dla określenia pewnych zjawisk artystycznych, pozostaje w jakimś stopniu problematyczne: ponieważ, aby uznać je za uprawnione, trzeba by uznać awangardę za jeden z nielicznych, jeśli nie jedyny, prąd myślowy, któremu udało się zupełnie oddzielić od swojego historycznego prekursora, lub - co stanowi łatwiejszą drogę - za prąd, który wchłonął historyczne awangardy i przekształcił je w szerszą formację, która zmieniła w pewnym stopniu część klasycznie przypisywanych historycznym awangardom cech $^{1}$.

\section{Awangarda, modernizm i ariergarda}

Przytoczenie - w bardzo skrótowej formie — problemów z rozróżnianiem dwóch typów definiowania awangardy miało posłużyć jako wstęp do przedstawienia pewnych dalszych komplikacji związanych z użyciem tego terminu. Uznając awangardę za prąd myślowy, odwolujemy się zazwyczaj do cech przypisywanych historycznym awangardom, uznając je za fundament myślenia o tym specyficznym ruchu. Tymczasem, jak przekonują nas liczni badacze, definiowanie awangardy historycznej, a dokładniej orientowanie jej wobec innych zjawisk $\mathrm{z}$ tego samego okresu, nie jest wcale zadaniem prostym. Do najtrudniejszych aspektów należy określenie relacji między awangardą a modernizmem.

Proste przeciwstawienie „wysokiego modernizmu” i „anarchizujących awangard” od stosunkowo dawna nie jest już uznawane za satysfakcjonujące. Spośród licznych sposobów nowego ustawienia relacji między wspomnianymi prądami za najbardziej interesującą i zarazem odpowiadającą rzeczywistości historycznej uznaję koncepcję Astradura Eysteinssona, który wskazuje, że u podstaw modernizmu tkwił nie spójny, ogarniający całą rzeczywistość projekt, lecz przeciwieństwa. Modernizm jest zatem dla badacza wcale nie równoznaczny z tym, co uznajemy za wysoki modernizm, lecz przestrzenią, która rodzi się między owym wysokim modernizmem a prądami awangardowymi, włącznie $\mathrm{z}$ futuryzmem czy dadaizmem (Eysteinsson 2004). Taka, rozszerzająca i włączająca wizja modernizmu stanowi oczywistą polemikę między innymi z koncepcjami Fredericka Jamesona (2002: 7) oraz remodeluje relację między modernizmem i postmodernizmem ${ }^{2}$.

Dla Eysteinssona awangarda jest prądem, który zachowuje pewną odrębność, lecz który funkcjonuje zdecydowanie jako część, nie zaś przeciwieństwo modernizmu. Dzieje się tak w sporym stopniu dlatego, że historyczne awangardy nie tylko kształtowały oblicze modernizmu, lecz również i dlatego, że nie sposób wyznaczyć ścisłych linii podziału nie tylko między cechami tych prądów, lecz przede wszystkim między konkretnymi osobami - na przykład zdaniem badaczy włączających awangardę do modernizmu rozstrzygnięcie, czy dorobek, zwłaszcza wczesny, Ezry Pounda należy do awangardy, czy do modernizmu jest po prostu niemożliwe. Natomiast próby rozdzielania konkretnych tekstów wydają się nie tyle nawet niecelowe, co trudne do uzasadnienia:

1 Oczywiście najbardziej problematyczną pozostaje dążenie do nowości istotne dla pierwszej awangardy, zdecydowanie mniej ważne lub w najlepszym razie odmiennie definiowane (na przykład jako dążenie do eksperymentu) obecnie.

2 Zdaniem Eysteinssona postmodernizm jest krytyczną, ale zdecydowanie kontynuacją modernizmu, nie zaś jego zaprzeczeniem, jak wyglądało to w przypadku tez Jamesona. 
W tym wypadku „modernizm” jest z konieczności terminem szerszym, podczas gdy pojęciu „awangardy” przysługuje dość znaczna swoboda interpretacyjna w ra ma ch całościowego zakresu modernizmu. Jednocześnie wszystkie zjawiska uznawane za modernistyczne podlegają wpływowi awangardy. (Eysteinsson 2004: 197)

Przesunięcia w definiowaniu awangardy i włączenie jej w nurt modernizmu, uważanego za formację szerszą, także w znaczeniu prądu myślowego, otwierają moim zdaniem przestrzeń, by postawić pytanie o użyteczność myślenia o awangardzie jak o ruchu ahistorycznym. Podkreślają one również istotny problem, jakim dla mówienia o awangardzie jako prądzie myślowym o obecnie - co najmniej — stuletniej tradycji jest kategoria nowości i oryginalności.

Sposobem wybrnięcia z owych - kolejnych już - terminologicznych problemów jest koncepcja stworzona przez Marjorie Perloff, badaczkę zajmującą się przez lata poezją, którą można określić za Eysteinssonem jako modernistyczną i awangardową równocześnie. Perloff w swoich kilku książkach wypracowuje z jednej strony koncepcję ariergardy, z drugiej zaś eksploruje „nieoryginalność, uznając ją za cechę współczesnej literatury, cechę, która jest wyraźnym zastępnikiem tego, czym dla historycznej awangardy miała być nowość.

Zanim bardziej szczegółowo omówię tę koncepcję, warto zdefiniować, jak Perloff rozumie ariergardę. Jest to zdaniem badaczki mniej nawet formacja myślowa, a bardziej — pewna strategia artystyczna. Koncepcja ariergardy została stworzona przez Perloff jako odpowiedź na spory dotyczące relacji między romantyzmem a modernizmem, modernizmem a awangardą, czy wreszcie między modernizmem a postmodernizmem. Koncepcja ariergardy warunkuje koncepcję nieoryginalności jako cechy współczesnej poezji oraz określa stosunek Perloff do takich pojęć jak tradycja czy pamięć kulturowa. Warto więc wyraźnie zaznaczyć, iż nie jest ona - i intencjonalnie nie ma być - neutralnym opisem rozwoju i przenikania poszczególnych prądów artystycznych, ale postulatem badawczym, wskazującym na najważniejsze cechy współczesnej poezji. Stąd też polemiczny charakter proponowanych przez badaczkę definicji, idących w sporym stopniu pod prąd utartym ramom podziałów na awangardę i modernizm.

Analizowane przez Perloff poetyckie techniki, takie jak kolaż, montaż, wielojęzyczność poematów czy łączenie w ramach jednej całości fragmentów literackich oraz wizualnych, lirycznych i dokumentalnych, czy wreszcie cytowanie jako świadoma gra z tradycją, stanowią zatem elementy szerzej pojmowanego programu artystycznego. Jednym z najważniejszych jego postulatów jest dążenie do wywikłania się z konieczności wyboru jednej z dwóch artystycznych dróg: kontynuacji tradycji lub odrzucenia przeszłości i odcięcia się od niej. Jak już wskazywałam, Perloff nie tylko opisuje wymienione przed momentem techniki, daje również jasno do zrozumienia, że są one optymalną odpowiedzią zarówno na wyzwania współczesnego, zdominowanego przez media świata, jak i na dążenie do zachowania w teraźniejszości cennych elementów przeszłości. Tym samym Perloff, analizując konkretne poetyki oraz związane z nimi realizacje artystyczne, poszukuje odpowiedzi na pytanie, co jest wyjątkowo wartościowego i zarazem unikatowego we współczesnej poezji (Perloff 2010).

Odpowiedzią jest zdaniem Perloff koncepcja ariergardy. Kategoria ta wywiedziona zostaje z badań zarówno nad współczesną poezją, jak i nad poezją modernistyczną i awangardową. Kluczowym dla badaczki przykładem strategii ariergardowych będzie między innymi poezja Ezry Pounda, przez innych badaczy określana raz jako modernistyczna, innym razem jako awangardowa, ze znaczącym wyjątkiem między innym Astradura Eysteinssona. Twórczość Pounda, analizowana przez Perloff wielokrotnie (por. zwłaszcza Perloff 1985; 1986), stanowi 
zdaniem badaczki jaskrawy sygnał, że sposób definiowania modernizmu, który przyjmuje na przykład Frederick Jameson (1991), jest głęboko sprzeczny. By ową sprzeczność pokazać, warto odwołać się nieco szerzej do tez badaczki.

Koncepcja „nieoryginalności” oparta jest na dwóch uzupełniających się, ale do pewnego stopnia odrębnych spostrzeżeniach. Pierwszym z nich jest teza, iż w ramach modernizmu można zidentyfikować wyraźne sygnały wskazujące na kształtowanie się poetyki, której najistotniejszym elementem jest postulat stworzenia modelu liryki równocześnie nietradycyjnej (niekontynuującej romantycznego modelu) i niezrywającej związku z szerzej pojmowaną literacką przeszłością.

Druga istotna teza Perloff dotyczy sposobu konstruowania tekstów uznawanych za nieoryginalne. Przekonanie, że indywidualność można pogodzić z czerpaniem inspiracji z innych, w tym i dawnych źródeł, prowadzi do poszukiwania konkretnych technik poetyckich, pozwalających na równoczesne nawiązywanie do literackiej tradycji i na innowacyjność. Owymi technikami było cytowanie, włączanie w wypowiedź elementów pochodzących z innych tekstów, kultur czy dzieł sztuki, a także kolaż.

Chociaż każda z tych technik, zwłaszcza cytowanie, miała już ugruntowaną tradycję, ich rozumienie w okresie kształtowania się koncepcji „nieoryginalności” było zasadniczo odmienne. Centon (Głowiński i in. 2002: 75), jeden z najbardziej znanych sposobów składania poematu $\mathrm{z}$ fragmentów innych tekstów, był traktowany raczej jako zabawa lub wyraz poetyckiego kunsztu niż jako sposób na stworzenie indywidualnego dzieła. By opisać, na czym ma polegać innowacyjność strategii „nieoryginalności”, warto krótko scharakteryzować, w jaki sposób zmieniało się rozumienie celów poezji i języka poetyckiego w dwudziestym wieku. Zdaniem badaczki możemy bowiem obserwować przebiegający dwufazowo zwrot, którego korzenie sięgają poezji awangardowej (Perloff 1985; 2010: 57), a szczególnie manifestu Filippo Tommaso Marinettiego. Rozluźnienie więzi między słowami, przebudowa całej struktury języka poezji i zbliżenie go do języka naturalnego, nowoczesnego, rezygnacja z prymatu znaczenia nad formą są najważniejszymi cechami kształtującej się w tamtym okresie koncepcji poezji.

Jednakże zanim poezja lingwistyczna, a także i poezja konkretna, zaczęły koncentrować się na próbach stworzenia poematu całkowicie zrozumiałego, dokonał się wspominany już zwrot. Początkowo uznawano poezję lingwistyczną za opozycyjną względem języka naturalnego, podkreślając jej oryginalność i moc kreowania wyjątkowej przestrzeni kulturowej. Jednakże już w początkach dwudziestego wieku możemy obserwować przejście od modelu oporu do modelu dialogu, dialogu z wcześniejszymi dziełami lub innymi tekstami kultury. Ów dialog pozwala na „pisanie w poprzek”, na uczestnictwo w szerszym, publicznym dyskursie oraz na przyłączanie nowych, wcześniej uznawanych ze odrębne elementów, a także na tworzenie wizualnych i dźwiękowych kompozycji maksymalne poszerzających intertekstualność określonych prac. Szczególnym przykładem realizacji owego dialogu jest zdaniem badaczki kolaż, działający w specyficzny, podwójny sposób - z jednej strony silnie zarysowany jest związek ze światem zewnętrznym, którego elementy stanowią części składowe kolażu, z drugiej jednak samo zestawienie poszczególnych elementów w jego ramach zmienia kierunek referencji: nie jest już nim świat zewnętrzny, lecz rzeczywistość wykreowana przez określone zestawienie fragmentów. Podobnie jest w przypadku kolażu literackiego: słowa odsyłają do przedmiotów i zdarzeń, niemniej sama struktura kolażu ową referencję podważa.

Perloff, charakteryzując specyfikę współczesnej poezji i podkreślając, jak istotna jest obecnie technika kolażu, nie unika wskazywania, że tradycja oraz poetyka modernizmu, trakto- 
wana jako jednorodna, są w rzeczywistości połączeniem pewnych koncepcji wywodzących się z odmiennych epok. Taki sposób charakteryzowania modernistycznego poematu sprawia, że częste określanie poezji Eliota i Pounda jako wysokiego modernizmu nie wydaje się być adekwatne, szczególnie jeśli uznajemy za główną różnicę między modernizmem a awangardą podejście do problemu nowości oraz koherentności dzieła. Literackie przykłady analizowane przez badaczkę (m.in. Ziemia jatowa oraz Cantos) wskazują na możliwość stosowania struktury cięć, montażu i kolażu jako samoświadomego projektu artystycznego, stanowiącego pomost między wyzwaniami awangardy i modernizmu. Tym pomostem jest właśnie strategia, którą Perloff określa mianem ariergardowej, a która korzysta z konceptu „nieoryginalności”, będącego twórczą odpowiedzią na dwa modernistyczne i awangardowe wyzwania, czyli przekształcania tradycji oraz dążenie do nowości. Warto zaznaczyć, że kategoria ariergardy jest przez Perloff stosowana w sposób anachroniczny: aby opisać pewien nurt, który nie mieści się ani w ramach awangardy, ani w ramach modernizmu, albo - stawiając sprawę nieco inaczej — sytuuje się dokładnie na ich pograniczu. Oznacza to, że o ile można mówić o pewnej awangardowej lub modernistycznej świadomości i umyślnie kształtowanych ramach poetyki tych prądów, o tyle ariergarda jest kategorią konstruowaną ex post, jako odpowiedź na powracający problem z podziałem między tymi zjawiskami. Tworzone przez Perloff pojęcie ma więc charakter głównie operacyjny: pozwala dostrzec i nazwać to, co wcześniej roztapiało się w sporach, zdaniem badaczki jałowych, o granice między awangardą i modernizmem, a co jest trwałą, trwalszą niż inne cechy tworzonej wówczas literatury, właściwością poezji, która ani nie chce z niczym zrywać, ani nie uznaje się za niczyjego bezpośredniego kontynuatora.

Podsumowując już, ariergarda nie dąży do zerwania z przeszłością, traktując propozycje dwudziestowiecznej awangardy z szacunkiem graniczącym z podziwem. Ariergarda związana jest $\mathrm{z}$ awangardą, jednak nie jest jej bezpośrednią kontynuatorką ani też nie kształtuje się w opozycji wobec jej poetyki. Związek między tymi dwiema formacjami dobrze oddaje militarna metafora: awangarda jest formacją nie tylko prestiżową, ale i narażoną na największe możliwe straty. Jej działania — choć spektakularne — najczęściej nie oznaczają wprowadzenia trwałej zmiany. Nowatorstwo i wysiłek podejmowany w celu zmiany określonego stanu rzeczy rzadko prowadzą do trwałego przedefiniowania zastanej rzeczywistości. Działania awangardy prawie zawsze kończą się więc klęską, choć klęska ta wliczona jest w model jej działania. Jej zadaniem jest wszak jedynie zainicjowanie zmiany, a niekoniecznie jej utrzymanie.

To zadanie należy raczej do ariergardy, która nie tyle ma zmieniać zastaną rzeczywistość, co utrwalać zmiany, jakie wprowadziła awangarda. Ariergarda ma zatem ratować to, co zagrożone i co zarazem — według już swoich własnych kryteriów — uważa za ratowania warte (Perloff 2010: 53).

\section{Awangardowe tradycje $w$ ariergardowych chwytach, czyli strategia poetycka Andrzeja Sosnowskiego}

Proponowana przeze mnie, za Perloff, koncepcja ariergardy wydaje się użytecznym i zarazem interesującym sposobem mówienia o współczesnym trwaniu awangardowych tradycji w literaturze. Kategoria ariergardy nie tylko usuwa problem, który określałam wcześniej jako zagadnienie ahistoryczności awangardy, ale pozwala również na dostrzeżenie wcześniej słabo omówionych zjawisk, jak łączenia - także we współczesnej praktyce literackiej - tradycji awangardowych i modernistycznych. 
Zwłaszcza metafora ariergardy jako formacji ocalającej to, co możliwe do ocalenia z postulatów ariergardy, wydaje się dobrze opisywać taktykę pisarską Andrzeja Sosnowskiego. Gdyby spojrzeć na cechy, jakie Perloff przypisuje ariergardzie, w zasadzie wszystkie znajdziemy w poezji Sosnowskiego. Były one również — podobnie jak nawiązania do zdaniem Perloff ariergardowych twórców, takich Pound i Eliot - opisywane przez krytyków. Równocześnie wyjaśnia to, dlaczego Sosnowskiego jest tak trudno przypisać do określonej tradycji. Rejestr nazwisk, które padają podczas próby odpowiedzi na pytanie o źródło inspiracji Sosnowskiego zmienia się wraz z każdym kolejnym tomem. Już po drugim krytycy rezygnują z uznania wpływu anglosaskiego modernizmu na rzecz wskazania — zapewne przez tytuł tomu - na zainteresowanie stylem Arthura Rimbauda. Wtedy pojawia się także sugestia czerpania przez polskiego poetę z praktyki artystycznej Johna Ashbery'ego (Zadura 1994: 113-114). Oczywiście, wszystkich tych inspiracji Sosnowski dość konsekwentnie się wypiera (Maciejewski, Majeran 1995), podobnie jak przypisywanych mu kolejnych poetyk, od zasadzającej sią na igraniu ze znaczeniami (Cisło 1994: 14) po operującą skojarzeniami i iluminacjami (J. Ł. 1994: 107). Jedynym wątkiem interpretacyjnym, którego Sosnowski nie neguje, jest skupienia na języku, próba osiągnięcia jego precyzji i potoczystości (Bryk 1996: 133), przekroczenia lub zatarcia granic między poezją i prozą oraz dążenie do uproszczenia języka (Wolski 1993: 162) i tropienia literackich sztancy (Kornhauser 1999: 12). Jak można jednak bez trudu zauważyć, owe diagnozy i próby określenia najważniejszych cech poezji Sosnowskiego są niezwykle ogólne i przypominają raczej etykietki, które można przypinać określonej poetyce, niż tropy interpretacyjne.

Egzemplaryczna jest pod tym względem rozmowa Sosnowskiego z Mariuszem Maciejewskim i Tomaszem Majeranem, w której poeta na pytanie, czy zgadza się z twierdzeniem Orskiego, że klasycyzm form jest medium dla najbardziej awangardowej opcji w liryce polskiej i czy taka postawa wobec tradycji jest jedną z możliwych tras ucieczki, udziela skrajnie wymijającej odpowiedzi, którą można by określić jako równoczesne potwierdzenie i zaprzeczenie. Jedyną wskazówką, jakiej Sosnowski udziela, jest spostrzeżenie, że najbardziej ceniona przez niego twórczość to taka, która wyzwala pewien rodzaj przyjemności w trakcie tworzenia:

Przyjemność komponowania tego rodzaju wiersza polega na tym, że trzeba znaleźć odpowiednią liczbę bardzo krótkich fraz, które da się złożyć w pewną wdzięczną całość, w której wszystkie wersy będą stały pod jakimś interesującym kątem do siebie. I najważniejszy jest efekt: kto tu mówi? Kto jest autorem? Taki wiersz wyprowadza na jaw dziwną samodzielność języka. (Maciejewski, Majeran 1995: 13)

W tej koncepcji naczelną wartością wydaje się wybór, wybór, który nie może być zawężany przez chęć uspójnienia, ujednolicenia, ogarnięcia i wcielenia cudzego słowa przez własne. Oczywiście, taka technika przypomina do pewnego stopnia - na co zresztą zwracała uwagę część badaczy — działania i modernistów, i twórców awangardowych, zwłaszcza zaś Pounda i Eliota. Wydaje się jednak, że zbyt szybkie przyporządkowywanie techniki Sosnowskiego do strategii tekstowych, charakterystycznych dla jednego z wymienionych twórców, może być upraszczające. Punktem oporu, różnicującym omawiane praktyki, wydaje się tutaj nie tyle ich sposób użycia, co cel. Jacek Gutorow zwraca uwagę na wątek tradycji literackiej jako stale powracający w wierszach Sosnowskiego, ale niełatwy do określenia. Badacz zauważa, że technika cytowania, której efektem jest zatarcie tożsamości, każdorazowo staje się grą podej- 
mowaną z tradycją, grą, której istotą jest sprawdzenie, czy i na ile osadzona w tradycji poezja może być nowatorska:

Jak się ma poezja Sosnowskiego w tradycji? Albo inaczej: czy w obrębie tradycji możliwa jest nowość, inauguracja? Sądzę, że jest to możliwe. (Gutorow 1997:47)³

Próbując określić, w jaki sposób ma być to możliwe, Gutorow zauważa, że za tradycyjne można uznać nie tylko ruchy odgrywania czy wpisywania się w tradycję, ale i zrywania z nią. Tym samym badacz podkreśla, że celem Sosnowskiego jest kontynuowanie tradycji zrywania $\mathrm{z}$ tradycją. Interesującym tropem, wskazującym na to, jak można rozumieć owo „tradycyjne zrywanie z tradycją” są spostrzeżenia Piotra Śliwińskiego, który wskazuje na pewnego rodzaju „jednorazowość” wierszy Sosnowskiego:

Poezja Sosnowskiego chce mieć jak najmniej wspólnego z kształtami gotowymi, nadającymi się do ponownego użytku: jest w pewien sposób jednorazowa i arbitralna, co może się dokonać jedynie za cenę rozprzężenia zastanego systemu literackich form oraz jawnej prowizoryczności przyjętych założeń i celów. (Śliwiński 1997: 69)

Prowizoryczność i jednorazowość nie są kategoriami jednoznacznie pozytywnymi, tutaj jednak badacz używa ich tak, jakby ich wartościowanie właśnie takie było. Dzieje się tak, ponieważ mają one podkreślać partykularność poezji Sosnowskiego, osadzenie jej w literackim tu i teraz. Owo tu i teraz jest jednak świadome miejsca, jakie zajmuje w literackiej tradycji, a zabiegi rozprężania literackich form oraz językowej składni mają za zadanie podważać pewien określony porządek. Ów porządek nie jest jednak wcale przekreślany, wręcz przeciwnie istnieje immanentnie $\mathrm{w}$ formie wierszy Sosnowskiego, będąc przedmiotem licznych zabiegów formalnych. Zarazem jednak w poezji Sosnowskiego stale powraca wątek tworzenia od początku, znalezienia punktu startowego, jak choćby w wierszu Szerokość poetycka zero:

Może właśnie takim ktoś cię pokocha,
zawiesił głos w tunelu. Lecz myśl
pomknęła górą przez hałas rozjazdów
a nasze ciała powlókł skafander
snu, nabraliśmy szybkości i serce
zakołysało się w gardle jak łza
gdy nastawnie, hangary, neony
krwotok detali w pociemniałych oczach
błyskał za nami jak warkocz komety -
jakiś bóg tam pracował po wszystkich godzinach

(Sosnowski 1994a: 5)

Pierwsza fraza, „może właśnie takim ktoś cię pokocha”, przywołuje na myśl słowa, jakimi pociesza się osobę, która przeżywa uczuciowe rozterki, którą się przekonuje, że nie musi się zmieniać, by być kochaną. To zdanie akcentuje z jednej strony potrzebę samoakceptacji,

3 W tym artykule podążam raczej ścieżką interpretacyjną wyznaczoną w stosunku do poezji Andrzeja Sosnowskiego przez Jacka Gutorowa niż przez Grzegorza Jankowicza, eksplorującego wątki postmodernistyczne w twórczości pisarza. Podobnego wyboru dokonywała również Joanna Orska (2004), eksponując wartość nieprzeładowanej przez nadmiar odniesień „ścieżki Gutorowa”. 
z drugiej jednak brzmi nieco protekcjonalnie przez formułę „właśnie takim”. „Właśnie takim”, czyli niedoskonałym, dziwnym, specyficznym, obciążonym jakąś wadą lub niewpisującym się w aktualne trendy. To sformułowanie suponuje, że istnieje przeszkoda w byciu kochanym, przeszkoda, która dla kogoś może nie być istotna lub nawet może być zaletą.

Pierwsze zdanie wiersza jest komunikatem, od którego podmiot się oddala, ucieka. Co ciekawe, poetyka kolejnych wersów, tym razem sugerujących, że podmiotem jest już jakieś „my”, zaczyna przypominać poetykę awangardową, zwłaszcza utworów Apollinaire'a, z jego fascynacją szybkością i technicyzacją. Zasadnicza zmiana tonu wiersza wskazuje na odrzucenie, przynajmniej chwilowe, postulatu bycia sobą na rzecz wpisania się w jakąś zbiorowość, w jakąś poetykę. Ruch ten można traktować jako wyraz niemożliwości tkwienia ciągle pod „poetycką szerokością zero”, w miejscu, gdzie nie sięgają żadne wpływy.

Utwór ten sygnalizuje wielokrotnie pojawiający się w twórczości Sosnowskiego motyw samotności na bocznym torze. Podobna strategia przyjęta została także w wierszu $\mathrm{Na}$ bocznym torze, na jatowym brzegu:

I przyszedł anonim: na jałowym biegu,

W zaułkach dni, bocznych lożach nocy -

Jakże dziwny sygnał przyniosła nam młodość

Jakby życie naprawdę było wystrzałem

Do biegu - gotowi - start przez masyw centralny

Czasu surowego jak sfinks w egipskim mroku

(Sosnowski 1994: 9)

Jałowy brzeg, mogący stanowić nawiązanie do „ziemi jałowej”, jest dla podmiotu miejscem, które sytuuje się poza głównym nurtem życia. Do pewnego stopnia pozostawanie na nim jest decyzją podmiotu, nieakceptującego konieczności startu w wyścigu życia. Poboczność, drugotorowość to cechy, jakie Sosnowski przypisuje swojej poezji. Równie ważną kategorią jest także kategoria spóźnienia, pojawiająca się w różnych kontekstach w wierszach poety. Jest ona szczególnie ważna dla wiersza o tym samym tytule co tom, czyli dla Sezonu na Helu:

Spóźnieni wchodzimy w lato, nasze zegarki

zostawmy na plaży. Czas też

miewa przygody, na przykład za chwilę

twój słoneczny sygnet zniknie w mokrym piasku

zachodząc w ulewie stóp tej smagłej gromadki [...]

I tak bardzo

jej potrzeba przestrzeni do życia lecz my mamy serca w plecaku i tylko sprzątamy

lasy starych umocnien, faszynowe płotki

zasypując czas lekką stopą

zasypiamy w piasku

(Sosnowski 1994a: 13)

Wiersz ten już od pierwszych wersów gra z kontekstem uważanym za kluczowy dla interpretacji całego tomu, a więc z odniesieniem do Sezonu $w$ Piekle. Tutaj wyeksponowaniu ulega dosłowne rozumienie frazy, czyli po prostu sezonu turystycznego na Helu. Podobne 
napięcie jest zauważalne, jeśli weźmiemy pod uwagę grę znaczeń w odniesieniu do czasu. Początkowe spóźnienie zmienia się w próbę pozostania poza czasem, odcięcia się od niego, co sygnalizuje jak najbardziej dosłownie rozumiane utracenie zegarków. Frazy powtarzające się w codziennej, potocznej mowie, są tu przywoływane i przekonstruowywane, poczynając od początkowego „sezonu na”, przez „serce w plecaku”, wskazującego i na tytuł piosenki, i odsyłające do określenia „buława w plecaku”, eksponującego z kolei praktycznie nieograniczone możliwości, do „lekkiej stopy”, stanowiącej tym razem nawiązanie do określenia „lekką ręką”. Konstrukcja tekstu jest asocjacyjna — jakieś określenie wywołuje skojarzenie, które rozwija się w ciąg metafor. Ich związek z pierwszym, początkowym określeniem, pozostaje dość luźny, ale mimo to możliwy do odtworzenia krok po kroku.

Podobny zabieg poeta stosuje także w nowszym o kilka lat wierszu Inaczej z tomu Taxi. Utwór ten prowokuje do intertekstualnego odczytania, przez świadomą grę z co najmniej dwoma utworami:

Pociąg nurza się w tonach, skupione sygnały

Na obrysach pędu - jakby ruch stanowił

Nagłe terytorium o plynnych granicach,

Pulsujący kontur puszczony po szynach

Obok stali, błysków, zgrzytów i kołysań,

Plazmę ciepła drżącą jak meduzia plama.

Nieduzia plama?

(Sosnowski 2003: 11)

Pierwszy wers, głównie dzięki użyciu charakterystycznego określenia, jakim jest „nurza” odsyła do Stepów akermańskich Adama Mickiewicza. Zastąpienie wozu pociągiem jest dość prostym zabiegiem, którego znaczenie komplikuje się, jeśli wziąć pod uwagę, że podobnego dokonał kilkadziesiąt lat wcześniej Julian Przyboś w wierszu Ów step styszany przed rokiem (Przyboś 1984: 209). Stanowi on jasne nawiązanie do Mickiewiczowskiego sonetu oraz w trochę bardziej skomplikowany sposób - całej tradycji romantycznej, do której Przyboś, początkowo nastawiony sceptycznie, w dojrzałej fazie twórczości powraca jako do niemożliwego do przekreślenia punktu odniesienia. Na pytanie, czy wiersz Sosnowskiego nawiązuje do Mickiewicza, czy też do Przybosia, czy - co moim zdaniem oznacza coś trochę innego Przybosia nawiązującego do Mickiewicza, nie ma dobrej odpowiedzi. Składnia tego utworu o wiele mocniej przypomina charakterystyczny dla Przybosia, zdynamizowany sposób opisu przestrzeni, ale ostatnie wersy zdają się radykalnie odcinać od obu źródeł inspiracjí

Tym samym Sosnowski zmusza czytelnika do tropienia znaczeń, do prób zrekonstruowania zawartych w swych wierszach sensów, sam — jako podmiot liryczny, jako „ten, który mówi” - pozostając na bocznym torze. Motyw tropienia znaczeń jest w poezji Sosnowskiego silnie eksponowany. Jednym z istotniejszych pod tym względem wierszy jest Trop $w$ trop z tomu Stancje. Warto poświęcić mu nieco uwagi, gdyż z jednej strony można go traktować jako opis konkretnej strategii tworzenia, konstruowania znaczeń, z drugiej zaś jako opis trudnego do uchwycenia, samodekonstruującego się działania języka:

4 Praktycznie identyczny zabieg zostaje zastosowany w utworze List znad Morza Biatego, w którym ostatni wers bezpośrednio nawiązuje do cyklu Sonetów krymskich, zarazem akcentując sceptycyzm wobec ich poetyki: „Tylko stoję pod słońcem we władzy ciężkiego omamu / I wypowiadam Twoje imię lampo Aladyna i Akermanu" (Sosnowski 2003: 9). 
No i ogień dogonił nas w połowie drogi i klapser już za moment da nam sygnał. Broczyliśmy, wróć, kroczyliśmy a teraz w nogi i z górki jak woda na młyn bez powietrza i bez ziemi, byle było o czym śnić. To proste jak piosenka,

tyle serca, taki gest.

$[\ldots]$

A jednak

nawet przez sen zostawiasz ślady i tylko niektóre z nich są całkiem jasne jak coś co nie przypomina krwi lub nią nie jest

(Sosnowski 1994b: 5)

Cały utwór został zbudowany z różnych, powtarzających się i często przekonstruowanych fraz, możliwych do zasłyszenia w codziennej komunikacji. Większość z nich można uznać za pseudofrazeologizmy symulujące związek z ugruntowanymi w polszczyźnie idiomami. Poeta sięga tu do najbardziej utartych, w zasadzie już w ogóle nietraktowanych jak frazeologizm określeń, takich jak „w nogi”, „woda na młyn” czy połowicznie przytoczone „z górki na pazurki”. Druga strategia przytoczeń opiera się na przekształcaniu wyrazów w sposób, który z kolei może przypominać figurę pseudoetymologiczną, jak zamiana „broczyliśmy” i „kroczyliśmy”. Nieustannie sugerowany jest jakiś, wcale niekoniecznie istniejący, związek między wyrazami, istnienie jakiejś wspólnej podstawy znaczeniowej lub etymologicznej, która usprawiedliwia płynne, naruszające do pewnego stopnia zasady składni, przechodzenie od jednej frazy do kolejnej.

Równie słuszne może być spostrzeżenie - także sugerowane w tekście - że zasada konstruowania wiersza przypomina nieco sposób pisania prostej piosenki, kiedy to współbrzmienia i rymy, tworzące rytm, decydują o konkretnych zestawieniach, a niekoniecznie znaczenia poszczególnych wyrazów. Tak konstruowany utwór uchyla się interpretacji, eksponując warstwę formalną, a dokładniej sposób przejawiania się funkcji języka w tekście. Zdaje się, że to język mówi tym tekstem, opanowuje go, stając się podmiotem, a nie przedmiotem komunikacji. To wrażenie jest zresztą charakterystyczne dla wielu wierszy Sosnowskiego, prowokując krytyków do ciągłego powracania do wątku funkcjonowania języka w twórczości autora Stancji.

Wydaje się, że tej cechy poezji Sosnowskiego nie wolno traktować jako izolowanej od intertekstualności. W gruncie rzeczy można bowiem uznać, że Trop $w$ trop składa się z cytatów, cytatów z potocznej mowy, raz zasłyszanych i przekształconych, powracających nie jako niezmienne echo, ale jako wariacja. Słowa w takim rozumieniu są jedynie śladami, i to już niedokładnymi, słyszanego języka. Funkcjonują w oderwaniu, przez co tropienie znaczeń, jakie noszą lub do jakich odsyłają, jest praktycznie niemożliwe. Owo odesłanie jest puste, jest tropem, który już niczego nie wskazuje, jest pozostałością starego porządku.

O krok dalej idzie Sosnowski w tomie Po tęczy. W dalszym ciągu poeta rozbija strukturę wiersza przez dodawanie różnego rodzaju wtrętów, teraz jednak dodatkowo opatruje je specyficznym komentarzem o niejasnym statusie. Przyjrzyjmy się poniższemu fragmentowi: 
Pijemy brandy czasu. Póki

wir, pijemy. Wir trinken und trinken

(Sosnowski 2007: 8)

Nawiązanie do Fugi śmierci Paula Celana jest tu zauważalne i sygnalizowane na co najmniej dwa sposoby. Po pierwsze przez podobieństwo rozpoczynającego fragment wersu do frazy „pijemy czarne mleko świtania”, po drugie zaś przez dosłowny cytat z niemieckojęzycznego oryginału „wir trinken und trinken”. Ten fragment jest zresztą wyraźną wskazówką dla czytelnika, wprowadzającą język niemiecki bądź też niemieckojęzyczną twórczość jako punkt odniesienia dla utworu.

Urywek ten, jako kryptocytat, jest dość łatwy do zlokalizowania. Co jednak szczególnie interesujące, w umieszczonej na końcu tomu nocie Sosnowski informuje czytelnika, że w tomie Po tęczy można znaleźć cytaty z tekstów Flauberta, Buchnera, Celana, a także Henry’ego Dargera, Adorna i Chlebnikowa (Sosnowski 2007: 45). Odnotowanie poszczególnych punktów odniesienia (acz bez podania tytułów tekstów) stanowi kolejny rodzaj gry z czytelnikiem, zapoczątkowanej w tomie Gdzie koniec tęczy nie dotyka ziemi i kontynuowanej w późniejszych zbiorach. W przypadku pierwszego możemy dowiedzieć się, że fragment partytury zakopiańskiej Witolda Szalona wchodzi w skład tekstu, zaś na zakończenie Sylwetek i Cieni jesteśmy informowani (ponownie w Nocie, umieszczonej przed spisem treści), że:

Fragmenty tak zwanego Kodeksu drezdeńskiego, towarzyszące dłuższemu utworowi pt. Seans po historiach, wybierałem, wycinałem i rozmieszczałem na specjalnych kartach razem z Elżbietą Siwecką — rezultatem tych prac jest wielobarwna, ładna makieta, którą przy okazji chętnie wszystkim pokażę. (Sosnowski 2012: 51)

Gra z czytelnikiem, podobnie jak eksplorowanie intertekstualności tekstu, pozostaje więc pewną stałą w twórczości Sosnowskiego, mimo - zauważalnych na przestrzeni ponad dwudziestu lat — zmian poetyk tomów, oscylujących raz w kierunku poetyk raczej modernistycznych, innym razem — zdecydowanie bardziej awangardowych.

\section{Podsumowanie}

Wytwarzanie ciągłego napięcia między nawiązaniem, przywołaniem cudzej twórczości i poetyki a chęcią pozostania na bocznym torze, w odosobnieniu, jest wyczuwalne na przestrzeni wszystkich tomów Sosnowskiego. Do pewnego stopnia można tę sytuację interpretować jako próbę wcielenia w tekst takich poetyk, które mogłyby być dominujące, jako chęć wyzyskania ich siły dla własnej poezji, przy jednoczesnym pozostawieniu czytelnikowi wyboru co do tego, czy uzna wiersz za zagarnięty przez cudzą mowę, wcielający ją, czy też rozbity i fragmentaryczny. Bez względu jednak na to, jaką perspektywę przyjmiemy, można zauważyć pewną tendencję. O ile w pierwszych tomach częściej spotykane są cytaty i kryptocytaty z tekstów poetyckich, o tyle w późniejszych wyraźna staje się praktyka, która coraz mocniej ewoluuje w stronę cytowania fragmentów jakby zasłyszanych, niewykluczone, że mających swój pierwowzór w tekście literackim, ale funkcjonujących już praktycznie jako wyrażenia potoczne.

Oznacza to, że przestrzenią zagarniającą i zagarnianą powoli staje się nie tylko literatura, ale i język jako narzędzie komunikacji. Ponadto, co moim zdaniem wyjątkowo istotne, zwłaszcza wczesne tomy Sosnowskiego grają co najmniej kilkoma poetykami, zwłaszcza zaś - wygrywają napięcie, jakie rodzi się między tradycją awangardy a tradycją wysokiego 
modernizmu. Ta cecha i zarazem specyficzna strategia przyjęta przez poetę opiera się nie tylko na świadomej grze z konwencją „nieoryginalności”, lecz również wyzyskaniem najbardziej ariergardowego z chwytów, a więc chwytu montażu, zestawienia pozornie tylko do siebie niepasujących elementów, tak by pokazać ich pokrewieństwo. Montaż pozwala na połączenie stylistyk uznawanych za odmienne, a więc i awangardowej, i modernistycznej, i postmodernistycznej, za pomocą chwytu, który — w nieco odmienny sposób — był charakterystyczny dla każdej z nich. Jego wykorzystanie objawia pokrewieństwo tych poetyk, zbyt często i zbyt latwo analizowanych w izolacji, zamiast $\mathrm{w}$ relacji do siebie. Użycie go - w różny sposób i w czasem skrajnie odmiennych celach - ujawnia podskórną ariergardowość poezji Sosnowskiego, która wybiera, przekształca i ocala elementy tradycji awangardowej, mieszając ją i łącząc z konwencjami, które czasem pozostają z nią w określonym związku (jak tradycja modernistyczna), czasem zaś są zupełnie osobne, ukazując swoją pieczołowicie skonstruowaną ,nieoryginalność”.

\section{Bibliografia}

Bryk Cezary (1996), Kaptan w otoczeniu btaznów, „Odra”, nr 12.

Cisło Maciej (1994), Flirt z Kaliope, „Nowy Nurt”, nr 6.

Eysteinsson Astradur (2004), Awangarda jako/czy modernizm, tłum. D. Wojda [w:] Odkrywanie modernizmu. Przektady i komentarze, red. Nycz R., Universitas, Kraków.

Głowiński Michał, Kostkiewiczowa Teresa, Okopień-Sławińska Aleksandra, Sławiński Janusz (2002), Stownik terminów literackich, Ossolineum, Wrocław.

Gutorow Jacek (1996), Szaleństwo i metoda, „Strony”, nr 1.

- (1997), Andrzej Sosnowski: być albo nie być i być, „Kresy”, nr 30.

J. Ł. (1994), „Odra”, nr 6.

Jameson Fredrick (1991), Postmodernism, or, the Cultural Logic of Late Capitalism, Duke UP, Durham.

- (2002), A Singular Modernity. Essay on the Ontology of the Present, Verso, New York-London. - (2007), The Modernist Papers, Verso, London-New York.

Kornhauser Julian (1999), Czyżby jezyk zapadt w karygodna drzemkę?, „Tygodnik Powszechny”, nr 23.

Maciejewski Mariusz, Majeran Tomasz (1995), 50 lat po Oświęcimiu i inne sezony, rozmowa $z$ Andrzejem Sosnowskim, „Czas Kultury”, nr 2.

Orska Joanna (2004), Sens jako seks (O Lekcji żywego jezyka. O poezji Andrzeja Sosnowskiego), „Odra”, nr 12. 
Perloff Marjorie (1985), The Dance of the Intellect. Studies in the Poetry of the Pound Tradition, Northwestern UP, Evanston Illinois.

- (1986), The Futurist Moment. Avant-Garde, Avant Guerre, and the Language of Rupture, University of Chicago Press, Chicago-London.

- (1991), Radical Artificle: Writing Poetry in the Age of Media, University of Chicago Press, Chicago.

- (2004), Differentials. Poetry, Poetics, Pedagogy, University of Alabama Press, Tuscaloosa.

- (2010), Unoriginal Genius: Poetry by Other Means in the New Century, University of Chicago Press, Chicago.

Przyboś Julian (1984), Utwory poetyckie [w:] Pisma zebrane, t. I, Wydawnictwo Literackie, Kraków.

Sosnowski Andrzej (1994a), Sezon na Helu, Stowarzyszenie Literackie „Kresy”, Lublin.

- (1994b) Stancje, Stowarzyszenie Literackie „Kresy”, Lublin.

- (2003), Taxi, Biuro Literackie, Legnica.

- (2007), Po tęczy, Biuro Literackie, Wrocław.

- (2012), Sylwetki i Cienie, Biuro Literackie, Wrocław.

Śliwiński Piotr (1997), Ponad, pod, pomiędzy, „Res Publica Nova”, nr 11.

Wolski Jan (1993), Nie tylko rozum, „Akcent”, nr 4.

Zadura Bohdan (1994), Otwarcie, „Twórczość”, nr 10. 